\title{
Caster Semenya - the questionable practice of gender verification
}

In May 2019, the Court of Arbitration for Sport confirmed the decision by the International Association of Athletics Federations (IAAF) to require hyperandrogenic female athletes such as Caster Semenya to reduce their testosterone levels to compete in certain races. While Ms Semenya is appealing this decision, the mere fact that it was made shows a level of 'prejudice, discrimination and racial bias' that is unacceptable. As Mahomed and Dhai ${ }^{[1]}$ point out in this issue of the $S A M J$, gender verification started when women were first allowed to participate in the Olympics in 1900, subjecting female athletes to invasive, embarrassing and humiliating procedures. These many decades of questionable scrutiny of successful female athletes, particularly those with backgrounds similar to Ms Semenya's, have shown the IAAF to be disrespectful of human rights and medical ethics, exhibiting a level of discrimination that would not be tolerated in other areas of international concern.

The recent ruling comes from Ms Semenya's challenge to IAAF's April 2018 rule change requiring hyperandrogenous athletes to medically lower their testosterone levels to below $5 \mathrm{nmol} / \mathrm{L}$ for a continuous period of at least 6 months. Quite apart from the human rights issues involved, this practice is highly unethical - in fact, the World Medical Association has warned doctors not to assist in implementing the decision. David McQuoid-Mason ${ }^{[2]}$ points out that Semenya and other athletes such as Dutee Chand are not ill. Any doctor who 'treats' these athletes by lowering their testosterone to allow them to compete in certain athletic events is therefore not providing healthcare or medical treatment, which, even if it were defined as treatment, would be futile.

Which brings us to an important scientific question - do Ms Semenya's testosterone levels in fact make her faster? Researchers affiliated to the IAAF released a study ${ }^{[3]}$ that claimed to show that women with high testosterone levels performed as much as $3 \%$ better than those with lower testosterone levels in a few events. However, the findings of this study were challenged by Pielke et al. ${ }^{[4]}$ as unreliable. They found significant anomalies and errors in the underlying data for the four events that they were able to access, including inclusion of times for athletes who had been disqualified by the IAAF for doping, duplicated athletes, duplicated times and phantom times - poor science that was almost certainly carried through the rest of the data, which, tellingly, were withheld. In spite of this the IAAF introduced the regulations.

The discrimination is clear here. Male athletes also have widely varying testosterone levels. Their relationship to performance is not a matter of scrutiny. Aside from hormones, Nordic skier Eero Mäntyranta, for example, has a genetic condition that causes excessive production of red blood cells - essentially allowing him natural 'doping' for endurance events. As Jalme Schultz writes in The Conversation, ${ }^{[5]}$ no-one has suggested that Mäntyranta, or other men with similar advantages, should muzzle their assets. She also points out that there are good reasons for dividing sport into male and female categories because there are studies that show that elite male athletes outperform elite female athletes by about $10 \%$, so this segregation is actually beneficial for women. The tricky part comes when you have to decide who is male and who is female and what happens when an athlete does not fit neatly into a definition of femaleness. And this is where the IAAF and their advisors have fallen down so badly, revealing a neat societal definition of 'femaleness' that defies scientific scrutiny. It is also worth noting that although Ms Semenya outruns most women in her specialist distances, she comes nowhere near the times posted by elite male athletes over the same distances, in spite of having testosterone levels that are allegedly 'male'. Caster Semenya and Dutee Chand are legally women and should be allowed to compete as such. Let's hope that sense will prevail in the appeal process.

\section{Bridget Farham \\ Editor \\ ugqirha@iafrica.com}

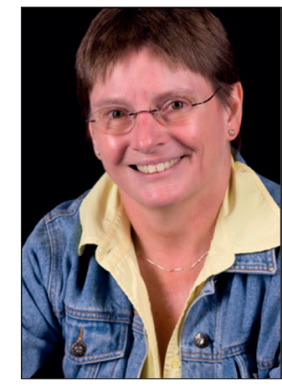

1. Mahomed S, Dhai A. Global injustice in sport: The Caster Semenya ordeal - prejudice, discriminatio and racial bias. S Afr Med J 2019;109(8):548-551. https://doi.org/10.7196/SAMJ.2019.v109i8.14152

. McQuoid-Mason D. Would it be ethical or legal for doctors in South Africa to administer testosteronereducing drugs to Caster Semenya? S Afr Med J 2019;109(8):552-554. https://doi.org/10.7196/ SAMJ.2019.v109i8.14146

3. Bermon S, Garnier P-Y. Serum androgen levels and their relation to performance in track and field: mass spectrometry results from 2127 observations in male and female elite athletes. Br J Sports Med 2017;51(17):1309-1314. https://doi.org/10.1136/bjsports-2017-097792

Med 2017;51(17):1309-1314. https://doi.org/10.1136/bjsports-2017-097792
Pielke R, Tucker R, Boye E. Scientific integrity and the IAAF testosterone regulations. Int Sports Law Pielke R, Tucker R, Boye E. Scientific integrity and the
(2019). https://doi.org/10.1007/s40318-019-00143-w

5. Schultz J. Caster Semenyảs impossible situation: Testosterone gets special scrutiny but doesn necessarily make her faster. The Conversation, 6 May 2019. https://theconversation.com/castersemenyas-impossible-situation-testosterone-gets-special-scrutiny-but-doesnt-necessarily-make-herfaster-116407 (accessed 15 July 2019).

S Afr Med J 2019;109(8):543. DOI:10.7196/SAMJ.2019.v109i8.14291 